\title{
Gifted Education Through the Lens of Religion
}

\author{
Nasser M. Almutairi ${ }^{1}$, Penny N. Round ${ }^{2}$ \& Niranjan R. Casinader ${ }^{2}$ \\ ${ }^{1}$ Ministry of Education, Saudi Arabia \\ ${ }^{2}$ Faculty of Education, Monash University, Australia \\ Correspondence: Nasser M. Almutairi, Ministry of Education, Jeddah 22826, Saudi Arabia. E-mail: \\ Nasser.almutairi75@gmail.com
}

Received: November 29, 2020

Accepted: January 11, 2021

Online Published: March 24, 2021

doi:10.5539/ies.v14n4p48

URL: https://doi.org/10.5539/ies.v14n4p48

\begin{abstract}
This paper aims to understand the influence of Islamic religious philosophy on the application of gifted education in schools. To date, little attention has been paid to the influence of religion, particularly Islam, on how giftedness or areas of talent are viewed and accommodated in the education system. The article considers that Islamic culture pays more attention to areas of talent, such as religious studies, leadership, wisdom and morality, with much emphasis on highly able people with spiritual, social and emotional needs. While in the West, religion may have less impact on gifted education which could be because of separating religion from the state. Therefore, a number of areas of giftedness/talent may be admired or ignored due to the influence of religion when it comes to educational practices. This paper gives an example of how Islam influences some areas of giftedness/talent such as music, art, sports and leadership.
\end{abstract}

Keywords: giftedness, gifted education policy, culture, religion, Islam, Saudi Arabia

\section{Introduction}

To date, little attention has been paid to the influence of religion, particularly Islam, on how giftedness or areas of talent are viewed and accommodated in the education system (Alamer, 2010; Aljughaiman \& Berki, 2013; Hein et al., 2014). An understanding of Islamic philosophy in relation to gifted education will provide a preliminary insight into the impact of educators' perspectives on gifted education practices in Saudi Arabia. The paper will address four areas that have an impact on educators' perspectives and educational practices in schools: religion and education, Islamic philosophy of education, the goal of life from an Islamic perspective, and perspectives of Islamic thoughts on giftedness.

While interviewing teachers during research for my $\mathrm{PhD}$, it became evident that the religious views expressed had a considerable influence on their attitudes and some gifted education practices. Moreover, I noticed much attention and admiration is paid to learning and practising certain Islamic values, such as memorising the Quran is considered to be a gift from Allah by teachers and parents of an Islamic school in Melbourne where my children were studying. Thus, I decided to delve into the connection between religion and gifted education, particularly how Islam, and more particularly the Saudi Islamic view, impacts on the interpretation of giftedness. These investigations would help to contextualise the Islamic understanding of giftedness and its influences on gifted education practices.

As non-Muslim scholars have presented many of the modern educational theories related to the education of gifted children, some of these theories may not fit the Muslim community, which differs in its religion, customs, behaviour and values. Therefore, Al-Jedaibi (2002) and Turkistani (2006) argue that Muslim scholars need to conduct studies from two perspectives. First, a scientific analysis of the Quran is required to incorporate the biography of the Prophet Muhammad and the integrated Islamic values into education of people with high ability. Second, current theories of giftedness should be filtered and revised for use in education in an Islamic context. This poses the question of how giftedness is seen through the lens of religion, especially that of Islam in the Saudi context.

The term 'giftedness' is a complex one and has already been the subject of many studies with a range of perspectives on the nature of giftedness (Coleman \& Cross, 2005; Kronborg, 2018; Sternberg, 2018; Sternberg et al., 2011). In order to apply this term in the Saudi context, there is a need to understand why Saudi educators see giftedness the way they do, and why many Saudis focus on the Quran and teachings of Prophet Muhammed as the 
definer of giftedness. Based on the different interpretations of Islam, there are three main schools of thought: Sufism, Sunni and Shi'ism (Denny, 2015) which may lead to different perspectives on some educational practices, including areas of talent. Because of the vast majority of Saudis represent the Sunni sect of perceiving and practising Islam, this paper reflects the Sunni sect in understanding the concept of giftedness.

A large majority of studies stress the point that religion in the West does not have the same high status or priority that Islam does with regard to the impact on people's lives and perspectives, especially in the field of education (for example, Beaudin, 2005). This situation emphasises the divergence of understanding of the notion of giftedness between Islam and the West, as well as Muslims who live in non-Islamic countries. In other words, whereas the religious context of Christianity in the West may not be explicit in most cases in academic discourse, the Islamic world sees that reference to religious text is normal and acceptable in academic fields (Aljughaiman \& Berki, 2013). Thus, ignoring cultural factors and relying on the same psychometric criteria applied in different cultures could affect how gifted students are identified (Sternberg, 2007). Moreover, current experts emphasise heavily the role of culture in determining what is considered intelligent in different cultures (Sternberg, 2018). It would be argued that culture has a big impact on formulating the concept of giftedness, especially when wondering whether there are specific areas of high ability that are admired more in different communities. By looking at this criterion of Marland's report (1972) which was adapted in the Saudi context (Aljughaiman \& Grigorenko, 2013), it can be seen that the Saudi context admire a number of areas due to religious and cultural factors. Thus, it is important to investigate the relationship between religion and educational practices to understand the impact of religion specifically on gifted education

\section{Religion and Education}

Generally, it is noticeable that religion does have an impact on people's perspectives and actions. In some countries, religious education is optional at school, while other countries have compulsory religious teaching at all schools and in all grades. Some schools focus more on religious teachings more than curriculum and identify themselves by their faiths, such as Catholic schools and Islamic schools. However, the impact of religion does not exist only at the level of religious schools but rather can be noticed at the level of an individual's religious commitment (Jeynes, 2004).

The impact of religion on the notion of giftedness has been noted by some studies that have identified different interpretations in different cultures. Ziegler and Stoeger (2007) argue that the meaning of the concept "gifted" in German was shaped by Christian traditions and comes from the passage of the Bible, "We have different gifts, according to the grace given us [Romans 12:6]" (p. 70). In addition, Grupp et al. (2003) believe that inventions and current discoveries are rediscoveries of previous creations of God and are not just the creations of mankind. In the same vein, Islamic beliefs influence Turkish perspectives of the terms intelligence, giftedness and intellectual achievement (Sak, 2007). However, in Thailand, more attention and respect have been paid to spiritual people for centuries (Anuruthwong, 2007). Leadership, morals and social skills have become more important areas since colonial times due to the impact of colonisation, which led to a dramatic shift in interpreting the concept of giftedness from the traditional understanding in Thai culture to the Western meaning of giftedness (Anuruthwong, 2007).

Thus, it is important to understand the value of the Quran in the Arabic language, as it is an unavoidable and central part of the various disciplines as well as the main academic source for understanding the Arabic language generally, and its grammar in particular (Aljughaiman \& Berki, 2013). As is shown in the following sections, it is common in the Saudi context to commit to and reflect Quranic verses or traditions of the Prophet Muhammad in academic fields. In addition, Islamic belief and teaching urges Muslims to use their exceptional abilities for supporting Islamic principles that pay more attention to certain areas, such as memorising and teaching the Quran, morality, serving the community and wisdom. It would be necessary to explain the aim of life from an Islamic perspective to shed some lights on its influence on the Muslim community.

\section{Islamic Philosophy of Education}

In general, Islamic education derives its educational principles from the Quran and the teachings of the Prophet Muhammed. Thus, the Saudi education policy is affected by the Islamic values in all aspects of life including education (Almutairi, 2008). Islamic education can be defined as those concepts that are related to one another in a single intellectual framework based on the principles and values of Islam. Metwali (1997) believes that Islamic education is a process of developing the talents of children in a balanced way that supports faith, science, morality and good work harmoniously, and which leads to the preparation of the Muslim character that fulfils Allah's commandments.

On the other hand, the objectives of Islamic education focus on developing the three components of the human: 
body, mind and spirit (Al-Jedaibi, 2002). Turkistani (2006) identifies five important goals of Islamic education:

1) The religious purpose, which defines man to his Creator and builds the relationship between them by the Lordliness of the Creator and the bondage of the creature.

2) The moral goal, which instils the love of good for others and praising good qualities and presents warnings for those with bad attributes.

3) The scientific goal, which seeks to form a scientific mentality that looks for wisdom in the principles of religion, behaviour and wise in social relations. It also calls for reflection on the creations of God. Allah said, "Indeed, in the creation of the heavens and the earth and the alternation of the night and the day are signs for those of understanding" [Quran 3:190].

4) The social goal, which focuses on the development of the social relations of the individuals. Such social relations follow the principle of brotherhood and adheres to the spirit of belonging to the community. Allah's Messenger said, "The similitude of believers regarding mutual love, affection, fellow-feeling is that of one body; when any limb of it aches, the whole body aches, because of sleeplessness and fever" [Book 32, Hadith 6258].

5) The mundane purpose of directing the individual to take care of vocational training in the face of material life. Building skills and abilities to work and seek a livelihood benefits the individual and society.

Education is considered one of the main aspects of life to which Muslims are paying attention especially religious studies which help to obey Allah appropriately. Thus, education plays a major role in directing Muslims to choose their priorities in life based on their level of commitment to religion.

\section{The Goal of Life from an Islamic Perspective}

To understand the Islamic goal of life, Muslims look to the Creator to understand the purpose for which he created humankind. As Muslims and believers in God, and believing that the Quran is His message and the constitution of our life, then Muslims should turn to Him to see what He says on this matter.

Islam is considered a method of life that contains many rules for managing people's lives and the communities (Ibn Kathir, reprinted 2007). Thus, it explains the rights of a person within community, family and the world. One of the areas that Islam is concerned with is education. Although Islam encourages the seeking of knowledge, when the first verse revealed from the Quran is "Read" [Quran 96:1], there are some limitations and prohibited areas of knowledge and educational practices that may restrict some modern educational practices. For example, Islam warns people not to teach and deal with magic, gambling and usury because of the expected negative outcomes related to such areas (Abou-Zaid \& Leonce, 2014).

\section{Giftedness: Perspectives from Islamic Thoughts}

Arab scholars have a range of terminologies for people with high ability (Khaleefa, 1999). These differences reflect both linguistic differences and terminology that capture creativity, giftedness, talent or genius (Alazraq, 2012). However, the common denominator among these terms is that the person described as having one of these qualities is distinguished in an unusual manner and different in their abilities and performance to other peers (Alazraq, 2012). He argues that high ability can be observed in personal behaviour, thinking skills, creative productions and unique handling of challenges and problems. Also, there are ongoing discussions about some terms such as giftedness, especially after translating them from the English language, as giftedness may mean mawhiba or tafwiq in Arabic (Rusan, 2012).

The Quran is not only a source of worship, but it is also considered the main source of the Arabic language that Arabic dictionaries refer to for an understanding of the meaning in different contexts. It is stated in Lesan Al-Arab (Arabic dictionary, which means the tongue of the Arabs) that "Wahhab" is one of the names of Allah who gives upon worshippers what He wants (Ibn Manthour, reprinted in 1994). The word "gives" occurs in many verses of the Holy Quran and indicates that God gives the talent. Solomon asked Allah, "My Lord, forgive me and grant me a kingdom such as will not belong to anyone after me. Indeed, You are the Bestower" [Quran 38:35]. Also, Allah says: "To Allah belongs the dominion of the heavens and the earth; He creates what he wills. He gives to whom He wills female [children], and He gives to whom He wills males" [Quran 42:49].

Going back through the Islamic ages, Muslims were interested in gifted children who had skills such as those related to intuition, the accuracy of observation, the power of memory and memorization, and the power of argument. Thus, members of the local community pushed these children to the councils of scholars who were taught religious subjects, linguistics, mathematics, medicine, philosophy and logic (Al-Qureaiti, 2013). Accordingly, many scholars have emerged in the history of Muslims such as Jabir Ibn Hayyan in Chemistry; 
Al-Razi and Ibn Sina in Medicine; Al-Farabi in Philosophy and Logic; Ibn Rushd in Medicine and Philosophy; Al-Khwarizmi in Algebra; and Ibn Khaldun in Sociology (Al-Qureaiti, 2013). However, the field of taking care of highly able people in Islamic culture is extensive, and it is difficult to limit them to one field or a concept. Thus, Aljughaiman and Berki (2013), Alazraq (2012), Al-Jedaibi, (2002), Turkistani (2006), and Baharith, (2013) refer to some giftedness/talent areas that are appreciated in the Islamic and Arab world:

1) Language abilities, which include the ability to absorb various languages, the possession of rich vocabularies, the ability to recite and memorise the Holy Quran, the ability to produce effective poems.

2) Logical capabilities, including super-ability with absolute numbers, conservation and arithmetic, and high mental ability in reasoning and solving a community's problems.

3) Moral abilities, which include the ability to self-control and distinguish with good attributes such as humility, justice, patience, honest and generosity.

4) Innovative engineering capabilities, including a high degree of proficiency in handling of places, spaces, directions, sizes, machines, shapes, materials, colours, etc. Creative people do not find it difficult to interact with all these different variables.

5) Creative abilities in activities of painting, sculpture, decoration, colouring, lines, etc. Hence, talented artists can present Islamic values through their creative work that reflect their religious commitment.

6) High leadership capabilities that include excellence in administrative work, so that leaders realise their objectives, find ways to achieve them and make a difference in their community.

7) Commitment to worship that includes superiority in worship and adherence to religious teachings that meet the commands of Islam.

8) Memorising the Holy Quran, which reflects a high ability not only when memorising around 600 pages, but also it shows a discipline to be among the 'best' Muslims. The Prophet said, "The best among you (Muslims) are those who learn the Qur'an and teach it" [Vol. 6, Book 61, Hadith 545].

9) Wisdom, which requires the interaction of four main components: (1) intelligence, (2) knowledge, (3) vision, which is the ability to balance various elements in making decisions, and (4) decisiveness, which is the ability to act decisively and make effective decisions.

The following sub-sections are examples of how religion in Saudi Arabia influences people's perspectives on areas of giftedness/talent involving music, visual arts, sports and leadership

\subsection{Music and Singing}

There are different discussions about the concept of music as well as the types of music that are restricted for religious reasons in Saudi Arabia. Music in the West is defined as the art of arranging the patterns of sounds for singing or playing on instruments (Stevenson, 2010), while the word music, musiqaa, in Lesan Alarab dictionary means a Greek word for playing musical instruments (Ibn Manthour, reprinted 1994). Gardner's theory of Multiple Intelligences (1983) describes musical intelligence as the ability to recognise rhythm, tone and pitch, and some studies in Saudi Arabia found the subjects of the study had very low scores in a musical intelligence test (Al Muhaidib, 2011). This result may reflect a problem with understanding what is meant by the word for music in the Saudi context. The word nashid is an Islamic way of singing without instruments that is for praise of Allah and His Prophets or for stimulating good character (Ibn Manthour, reprinted 1994), whereas the concept of music that is tested by the musical intelligence test may be interpreted differently in the Saudi context and confuse students and teachers.

There are diverse views amongst Islamic scholars about music that are due to the different interpretations of Quranic verses and prophetic hadiths (words and actions of the Prophet Muhammad). Even though all Islamic scholars agree on the basics of Islam, there is some disagreement on secondary issues, especially when judging current issues that did not exist at the time of the first generations of Islam. Thus, some scholars allow some music in Islam while others forbid it.

One of the main reasons for permitting some music in Islam is the absence of clear evidence from the Quran and authentic hadiths. Al-Qaradawi (2013) does not find any clear statement indicating that listening to music is haram (prohibited) in Islam. Thus, music that contains lyrics with themes of the prophet or religious festivities are preferred and has a positive impact on soul and heart (Al-Qaradawi, 2013; Berglund, 2008). In contrast, music that contains sexual, aggressive or racist lyrics is forbidden. However, the previous Saudi Grand Mufti, Ibn Baz (1987) argued that this narration and a similar one can be interpreted differently. Instead, Islam encourages Muslims to memorise and recite the Quran in a nice voice and considers those who achieve that to be amongst the 'best' 
Muslims.

As a result of the above discussion, the Ministry of Education in Saudi Arabia does not allow the teaching of music. Moreover, in non-Islamic countries, some students and parents refuse to participate in musical activities for the same religious reasons. In fact, the religious factor contributes to misunderstanding about acceptance of several kinds of music appreciated by others. For instance, when Sana, a primary school teacher of Islamic education in Sweden, showed her class a musical video of "pop songs" of a young Muslim singer, some children said that pop music is forbidden (haram) (Berglund, 2008). Likewise, Adely (2007) found that fewer males than females participated in music in Jordan. This motivated her to investigate the perspectives of Jordanian high school students about music. One of the participants explained that "the song we sing is moral and it is a national song". With regard to the question as to whether Muslims consider music to be permitted or prohibited, a girl replied that "only instrumental music is prohibited haram but here I recite poetry, and Hanan plays def (drum), the song we do here is not forbidden". Therefore, there is increased complexity as there are children who were born in Western societies living in Saudi Arabia who are influenced by religious interpretations.

To sum up, the desire to participate in music may depend more on cultural and religious values. In other words, some cultures believe people who perform well in music are talented while others minimise the value of music and place more importance on areas such as science. The different interpretations of the meaning of music in Islam leads to different practices of listening to music, which may be a reflection of the religious commitment level of individuals. In Islamic belief, the concept of giftedness in music differs from that understood in the "West", where followers of Islam consider people who recite the Quran in a nice voice as being talented (Stenberg, 2007). Thus, the Saudi system of education and some international Islamic schools do not allow teaching music, and the conflict may happen when adopting activities that include music in the classroom.

\subsection{Arts}

Beaudin (2005) argues that the concept of art differs between West and East for cultural reasons. The influence of religious and cultural factors can be noted in different areas of the arts. The types of Islamic art are affected by the traditions of Islam. Although the three schools of Islamic thought (Sunni, Shi'i and Sufi) have different interpretations in some areas, they are similar in their view of the beauty of art (Beaudin, 2005). It is narrated that the Prophet Muhammad said, "God is beautiful, and He loves beauty", which assumes that if God is beauty, all his creations should be beautiful (Beaudin, 2005). However, the notion of beauty not only refers to the material objects of living but rather indicates the "human norm" that includes beauty of spirit and soul (Eaton, 2004, as cited in Beaudin, 2005). In addition, Islamic arts can be seen in several areas of the arts such as architecture, painting the words of the Quran and creativity in solving problems. For example, glorifying the message of the Quran through painting the entire verses in the early Kufic script was appreciated and considered a creative art at the Metropolitan Museum in New York (Beaudin, 2005).

However, the impact of religion restricts the practice of some activities in arts due to the teaching of the Quran and the Prophet Muhammad. For example, a well-known hadith mentioned that "the people who will receive the severest punishment from Allah will be the picture makers" [Vol. 7, Book 72, Hadith 834]. However, this hadith has different interpretations as it may refer to a portable image that is worshipped, thus making the creator a maker of idols, while other interpretations refer to the general statement of making pictures. The idea of creating idols as a kind of art is criticised in both Islam and the Hebrew religions as it conflicts with the tenets of the Quran and the Bible (Beaudin, 2005). Some religious scholars accept the warning about drawing animated objects and have agreed to ban this kind of art (Al-Qaradawi, 2013). However, most scholars permit drawing of incomplete pictures of animals or human as it does not reflect the challenge of simulating the creation of God (Islamweb, 2002). Some interpretations indicate the permissibility of drawing any animated objects as long as the intention is education and learning rather than aiming to create what only God does.

With regard to the modern impact of technology and globalisation, Al-Qaradawi (2001) urges Muslim movie directors to produce cartoon films that stimulate and reflect Islamic values. On the other hand, Ibn Baz (n.d.) believes that drawing animated animals is unlawful and should be banned. There are other forbidden areas in Islamic education such as producing dramatic serials about people who represent prophets. The contemporary scholars agree that representation of the prophets is forbidden in general because it is disdainful and disrespectful to them (Islamqa, 2011). Their representation may weaken the ideal image that has been associated with them in the minds of people and people may also associate the image of that actor with their image of that prophet. Therefore, Islam supports art as long as it does not conflict with its teachings.

Given the Islamic interpretations of the permissibility of art, concern about this area can be found among teachers, parents and students. Alamer (2010) finds that, for religious reasons, parents and students in Saudi Arabia have a 
concern about visual arts. Even though the Saudi Ministry of Education set up a subject for art, students are required to draw or do crafts that reflect the Islamic teachings as well as society's moralities. Determination of talent in some areas of art in Islam depends on the different interpretations of religious scholars, which have an impact on educational practices.

\subsection{Sports}

Generally, Muslim girls are facing difficulties in participating in many modern physical activities. An American Muslim girl mentioned that "Because I am Muslim, I cannot wear a swimsuit". Hamzeh and Oliver (2012) used this statement as the title for their 12-month study that investigated the challenges facing Muslim girls in participating in physical education, for example, swimming and playing basketball with boys. In the same vein, Alamri (2015) points out that some activities were challenging for Muslim girls because of Islamic dress code and mixed gender activities, despite the variety of activities provided, which indicates the importance of raising educators' awareness of the impact of culture, race and religion on physical education. The Saudi Ministry of Education had neglected physical education for girls since establishing schools, but since the beginning of the 2018 academic year, girls have now had an opportunity to access physical education (Ministry of Education, 2017). The fear of participating in or establishing such physical activities is due to the fear that it may not fit with the Muslim environment.

Although physical education is appreciated in the Islamic world, some kinds of sports are criticised for religious reasons. Accordingly, it is advised to stay away from practising in some sports (Abd al-'Āṭi, 1995), rather than being identified as talented in areas that could be developed. It is considered that violent games such as boxing and free wrestling involve brutality and aggression that allow a player to inflict severe damage to the opponent's body. Consequences of this damage may sometimes lead to death and may also cause enmities, quarrels and hatred. Islamweb (2017) emphasises that this is haram as it is not permissible to harm oneself or others, especially hitting a face even when someone wants to defend himself.

\subsection{Gender and Leadership}

Leadership is considered an important domain of giftedness in some theories. Marland's (1972) definition of giftedness, which was adapted in the Saudi context (Aljughaiman \& Grigorenko, 2013), emphasised the importance of meeting gifted students in leadership. However, Alamer (2010) found that most Saudi male participants in his study believe that leadership can be seen only in males, while females perceive the ability of leadership as being applicable to both genders. This disagreement is based on the different cultural and religious interpretations among the participants (Alamer, 2010). Interestingly, the males attributed their perspectives to their religious views, which state that women are not naturally able to be leaders, while females believe they can do so and attribute this resistance to the nature of Saudi culture, which prevents them from participating in social activities (Alamer, 2010).

\section{Conclusion}

Religion has a significant influence on how giftedness/talent is perceived. This paper illustrated how giftedness is seen from the perspective of Islam. Life in Islamic teaching aims to worship Allah alone and follow His commands through the Holy Quran, which is considered to be giftedness in Islamic societies (Freeman, 2005). Islam is not only a religion but is also a set of instructions that must be integrated into all aspects of life. It rejects the principle of secularism that believes in segregation of state and religious practices. Secularism could be one example that differentiates between culture and religion when Islam is considered as a way of life in the Saudi culture compare to other cultures. Denman and Hilal (2011) indicated that "the Islamic religion is considered as much a part of the Saudi identity" (p. 304). Hence, Islamic values provide the frame for education. They encourage the seeking of knowledge to achieve the purpose of life, and prevent certain practices that hinder the achievement of Allah's satisfaction.

As a result, conflict may arise when Saudi Arabia adopts Western programs and theories about giftedness, which may have developed from a background of a Christian ethos. It is argued that implementing the "practice of importing methods of studying creativity, intelligence and giftedness without rigorous adaptation is handicapping [for Arab gifted education]" (Khaleefa, 1999 p. 25). It is necessary, therefore, to reform the concepts of giftedness, intelligence and creativity so that they fit the Arab world (Alazraq, 2012; Baharith, 2013; Khaleefa, 1999; Subhi-Yamin, 2009).

It might be argued that there is an alignment to some extent between Western theories and Islamic teachings regarding the concept of giftedness. However, Islamic culture pays more attention to other areas of talent, such as religious studies and morality, with much emphasis on highly able people with spiritual, social and emotional 
needs. Another major difference between giftedness in the West and in the Islamic culture is the commitment toward religion. For instance, Islam influences the majority of Muslims' perspectives and practices due to considering Islam as a way of life. Therefore, a number of areas of talent may be admired or ignored due to the influence of religion when it comes to educational practices. Thus, teachers, gifted program designers and policymakers should consider religious and cultural factors when creating programs and services for gifted students.

\section{References}

Abd al-'Ạțī, H. (1995). Islam in focus. Doha, Qatar: Ministry of Awqaf and Islamic Affairs.

Abou-Zaid, A., \& Leonce, T. (2014). Religious pluralism, yet a homogenous stance on interest rate: The case of Judaism, Christianity, and Islam. Contemporary Economics, 8(2), 219-228. https://doi.org/10.5709/ce.1897-9254.142

Adely, F. (2007). Gender struggles: Nation, faith and development in a Jordanian high school for girls (Doctoral dissertation). Retrieved from http://search.proquest.com/docview/304858982/

Al Muhaidib, N. (2011). Multiple intelligences: Identifying student diversity among Saudi female ESL learners. International Journal of Applied Educational Studies, 12(1), 33-40.

Al Qarni, M. A. (2010). Evaluation of provisions for gifted students in Saudi Arabia (Doctoral dissertation or Master's thesis, University of Wollongong) Semanticscholar. [PDF] Evaluation of provisions for gifted students in Saudi Arabia, Semantic Scholar.

Alamer, S. (2010). Views of giftedness: The perceptions of teachers and parents regarding the traits of gifted children in Saudi Arabia (Unpublished doctoral dissertation). Monash University, Melbourne, Australia.

Alamri, A. A. (2015). How Australian female Muslim students interpret challenges in high school sports. Journal of Muslim Minority Affairs, 35(2), 215-229. https://doi.org/10.1080/13602004.2015.1051752

Alazraq, A. (2012) Altafawuq $w$ almawhibat $w$ al'iibdae: 'iishkaliat almafahim bayn altatabuq $w$ alaikhtilaf [Giftedness, Talent and Creativity: The Problematics of Concepts between Match and Difference]. Retrieved from http://search.mandumah.com/Record/483694

Al-Jedaibi, R. (2002). Rieayat almawhubin fi zili manhaj altarbiat al'iislamia [Giftedness in the Islamic education curriculum]. Dar Shams.

Aljughaiman, \& Berki, M. (2013). Wisdom and giftedness: Perspectives from Arabic thought. Gifted Education as a Life-Long Challenge: Essays in Honour of Franz Mönks. Muenster, Germany: LIT-Verlag. Retrieved from https://aljughaiman.net/wp-content/uploads/2012/06/Wisdom-and-Giftedness-Perspectives-from.pdf

Aljughaiman, A. M., \& Grigorenko, E. L. (2013). Growing up under pressure: The cultural and religious context of the Saudi system of gifted education. Journal for the Education of the Gifted, 36(3), $307-322$. https://doi.org/10.1177/0162353213493153

Almutairi, N. (2008). The influence of educational and sociocultural factors on the learning styles and strategies of female students in Saudi Arabia [Doctoral dissertation, University of Leicester]. ProQuest. http://search.proquest.com/docview/301700420/

Al-Qaradawi, Y. (2001). Fatawa muasirah: istima'a ila almusiqa [Contemporary interpretations: listening to songs]. Retrieved from http://www.qaradawi.net/site/topics/article.asp?cu_no=2\&item_no=392\&version=1 \&template_id=8\&parent_id=12.

Al-Qaradawi, Y. (2004). Dirasat mustafidat lilqardawii hawl huquq almar'at alsiyasia [An extensive study about woman's political rights]. Retrieved from http:/www.almotamar.net/news/10623.htm

Al-Qaradawi, Y. (2013). The lawful and the prohibited in Islam. Islamic Book Trust.

Al-Qureaiti, A. (2013) Almawhubin walmutafawiqin : khasayisuhum waiktishafatihim warieayatahum [Gifted and talented: their characteristics, identification and provision]. Dar Alam Alkutub.

American Psychological Association. (1972). Ethical standards of psychologists. Washington, DC: American Psychological Association.

Anuruthwong, U. (2007). Thai conceptions of giftedness. In S. N. Phillipson, \& M. McCann (Eds.), Conceptions of giftedness: Sociocultural perspectives (pp. 99-126). Lawrence Erlbaum Associates. https://doi.org/10.4324/9781003064435-4

Baharith, A. H. (2013) Mafahim fi almawhibat wal'iibdae w ealaqatihima bialbaed alhadarii fi daw' nizam 
al'islam altarbuiu [Concepts of giftedness and creativity and their relation with cultural dimention in the light of the Islamic education system]. Faculty of Education Al-Azhar University Journal, 1(155), 178-256.

Beaudin, R. H. (2005). "And God created...” creativity in Islam. International Journal of Kurdish Studies, $19(1 / 2), 91$

Coleman, L. J., \& Cross, T. L. (2005). Being gifted in school: An introduction to development, guidance, and teaching (2nd ed.). Prufrock Press.

Denman, B. D., \& Hilal, K. T. (2011). From barriers to bridges: An investigation on Saudi student mobility (2006-2009). International Review of Education, 57(3-4), 299-318. https://doi.org/10.1007/s11159-011-9221-0

Denny, F. (2015). An introduction to Islam. Routledge. https://doi.org/10.4324/9781315663821

Gardner, H. (1983). Frames of mind: The theory of multiple intelligences. Basic Books.

Grupp, H., Domingue-Lacasa, I., \& Friedrich-Nishio, M. (2003). The national German innovation system: Its development in different governmental and territorial structures. In L. V. Shavinina, (Ed.), The international handbook on innovation (pp. 1018-1043). Elsevier. https://doi.org/10.1016/B978-008044198-6/50068-1

Hamzeh, M., \& Oliver, K. L. (2012). "Because I am Muslim, I cannot wear a swimsuit”: Muslim girls negotiate participation opportunities for physical activity. Research Quarterly for Exercise and Sport, 83(2), 330-339. https://doi.org/10.5641/027013612800745167

Hein, S., Tan, M., Aljughaiman, A., \& Grigorenko, E. L. (2014). Characteristics of the home context for the nurturing of gifted children in Saudi Arabia. High Ability Studies, 25(1), 23-33. https://doi.org/10.1080/13598139.2014.906970

Ibn Baz, A. (1987). Sifat salat alnabi sal la Allah alaih wa salam [The prophet's pray peace be upon him]. Retrieved from http://www.binbaz.org.sa/mat/1610

Ibn Baz, A. (n.d.). Fatwa noor ala aldarb [Interpretations: Light on the road]. Retrieved from http://www.binbaz.org.sa/mat/4841

Ibn Kathir, E. (Reprinted 2007). Tafseer Alquran Alazeem [The translation of the holy Quran]. Dar Taibah.

Ibn Manthour, M. (Reprinted 1994). Lesan Alarab [Arab tongue]. Dar Sader.

Islamqa. (2011). Hakam mushahadat al'aflam walmuslisalat alty tumathil al'anbia' walsahhaba [Ruling on watching films and serials that represent prophets and companions]. Retrieved from https://islamqa.info/ar/158232

Islamweb. (2002). Maenaa hadith: 'ashada alnaas edhabaan yawm alqiamat almusawirun [The meaning of the hadith: The most severe punishment on the Day of Resurrection]. Retrieved from http://fatwa.islamweb.net/fatwa/index.php?page=showfatwa\&Option=FatwaId\&Id=17331

Jeynes, W. H. (2004). Comparing the influence of religion on education in the United States and overseas: A meta-analysis. Religion and Education, 31(2), 83-97. https://doi.org/10.1080/15507394.2004.10012342

Khaleefa, O. (1999). Research on creativity, intelligence and giftedness: The case of the Arab world. Gifted and Talented International, 14(1), 21-29. https://doi.org/10.1080/15332276.1999.11672902

Marland, S. P. Jr. (1972). Education of the gifted and talented (Vol. 1). Report to the Congress of the United States by the Commissioner of Education. Washington, DC: U.S. Government Printing Office.

Metwali, M. (1997). Madkhal 'iilaa tarikh altarbiat al'iislamia [Entrance to the history of Islamic education]. Dar Alkhuraigy.

Ministry of Education. (2017). Applying physical education in girls schools. Retrieved from https://www.moe.gov.sa/ar/news/Pages/edu-sport.aspx

Rusan, F. (2012) Asalib alqias waltashkhis fi altarbia alkhast [Methods of measurement and diagnosis in special education]. Dar Al-Fikr Publishers \& Distributors.

Sak, U. (2007). Giftedness and the Turkish culture. In S. N. Phillipson, \& M. McCann (Eds.), Conceptions of giftedness: Socio-cultural perspectives (pp. 283-310). Lawrence Erlbaum Associates.

Sternberg, R. (2018). Theories of intelligence. In S. I. Pfeiffer, E. E. Shaunessy-Dedrick, \& M. E. Foley-Nicpon (Eds.), APA handbook of giftedness and talent (pp. 145-161). Springer, Dordrecht. https://doi.org/10.1037/0000038-010 
Sternberg, R. J. (2007). Cultural concepts of giftedness. Roeper Review, 29(3), 160-165. https://doi.org/10.1080/02783190709554404

Stevenson, A. (Ed.). (2010). Oxford dictionary of English. Oxford University Press.

Subhi-Yamin, T. (2009). Gifted education in the Arabian Gulf and the Middle Eastern regions: History, current practices, new directions, and future trends. In L.V. Shavinina (Eds.), International Handbook on Giftedness (pp. 1463-1490). Springer, Dordrecht. https://doi.org/10.1007/978-1-4020-6162-2_76

Subotnik, R. F., Olszewski-Kubilius, P., \& Worrell, F. C. (2011). Rethinking giftedness and gifted education: A proposed direction forward based on psychological science. Psychological Science in the Public Interest, 12(1), 3-54. https://doi.org/10.1177/1529100611418056

Turkistani, A. (2006). Munahij alnabii salaa allah ealayh wasalam fi tarbiat almawhubin [The approach of the Prophet Muhammad in gifted education] (Unpublished Master's Thesis). Umm Al Qura University, Saudi Arabia.

Ziegler, A., \& Stoeger, H. (2007). The Germanic view of giftedness. In M. McCann, \& S. N. Phillipson (Eds.), Conceptions of giftedness: Sociocultural perspectives (pp. 65-98). L. Erlbaum Associates. https://doi.org/10.4324/9781003064435-3

\section{Copyrights}

Copyright for this article is retained by the author(s), with first publication rights granted to the journal.

This is an open-access article distributed under the terms and conditions of the Creative Commons Attribution license (http://creativecommons.org/licenses/by/4.0/). 